\title{
The Impact of Employee Engagement on Productivity: A Case of the Egyptian Public Sector
}

\author{
Dr. Rania Sokrat \\ Business Administration Department \\ Canadian International College \\ Arab Republic of Egypt \\ Rania_sokrat@cic-cairo.com
}

\begin{abstract}
There has been a significant lack of Employee engagement study in the academic literature, which in return resulted in lack of knowledge about its consequences on the governmental sector «Alan M. Saks, (2006)».

It was found that engaged employees tend to be energetic and considerably enthusiastic about their work and in result higher organization's productivity is achieved «Bakker \& Demerouti, 2008». A positive relationship between organization's productivity and employee engagement was found, meaning that the more engaged the employee, the better he performs; and thus the better the organization's overall performance «Alan M. Saks, (2006)».

After careful consideration of the Egyptian sector and its status, it was found that an examination of the the employee engagement's impact on Egyptian Public sector is highly needed. Thus, the purpose of this study is to examine the employee engagement's impact on Egyptian Public sector.
\end{abstract}

Keywords: Employee engagement, Organization's Productivity, gender, Public sector.

\section{Introduction}

The administrations have come to the realization that the world is evolving, and that employees now form a serious difference due to the advanced efficiency and productivity that is now required, thus employee engagement became a significantly popular managerial concept and received a significant amount of attention. (Johnson, 2004) (Macey, et al., 2009).

Employee engagement results in expressively high outcomes, increases employee's performance and commitment, and has a positive relationship with organizational performance, productivity, profitability, loyalty and safety (Lawler, 2008)

\section{Hypotheses}

1- There is a Positive relationship between Managers and employee engagement.

2- There is a Positive relationship between organizational cognition and employee engagement

3- There is a Positive relationship between Clarity of responsibilities and employee engagement.

4- There is a Positive relationship between compensation and employee engagement.

5- There is a Positive relationship between training and employee engagement.

6- $\quad$ There is a Positive relationship between employee engagement and performance.

7- Employee engagement is affected by managers, organization cognitive, compensation, clarity of responsibilities, and training.

\footnotetext{
* This article was submitted in November 2018, and accepted for publishing in March 2019, Published: September 2020.

(c) Arab Administrative Development Organization- League of Arab States, 2020, pp 301-310، DOI: 10.21608/aja.2020.111868
} 


\section{Objective of the Study}

1- To identify the importance of this topic and how can the employee engagement affect the performance of the Egyptian public sector.

2- To identify the not capital of engagement and how those drivers can affect employee engagement.

3- To examine the effect of the employee' engagement on productivity.

\section{Definition of Employee Engagement}

One of the most widely used terms these days is employee engagement. Engagement itself is an emotional state that leads to the person being involved and loyal (Robinson, et al., 2004) (Schaufeli, 2013). Engaged employees can be described as individuals who are pleased with their job, get the needed amount of self-actualization from their job role, feel committed to the company, speak highly of it, and support the company be successful and achieve its objectives. (Mori, 2008) (Blessing White, 2008).

Engagement is a positive attitude where an employee does more than his job requires and focuses on the organization's benefit rather than his. (Robinson, et al., 2004)

Employee engagement is the outcome of how employees feel about the organization, leaders, and the work environment' (Mercer, 2007) (Kahn's definition, Maslach, Schaufeli and Leiter,2001, p. 417). It is preforming personally satisfying activities that enhance a staff member's sense of professional worth (Leiter and Maslach, 1998), affects employee's morale, production, commitment, loyalty, absenteeism rate, as well as, turnover rate. (Macey and Schneider, 2008). (Schmidt, and Hayes, 2002: 269), and must be measured with different tools (Schaufeli, et al., 2002). A culture that enables employee engagement needs staff who are prepared to go the extra mile to achieve better financial performance (Basis, 2010) (Baumruk, 2006).

\section{The Importance of Employee Engagement}

At this critical time, the increased attention from the government to employee engagement is highly required and will lead to achieving the government's goals, as well as, increase its productivity.

Gallup's study, which was demonstrated on 142 countries in 2015; showed that 13\% of Egypt's employees are «engaged» and mentally committed to their jobs and likely to be making positive contributions to their organizations. However, 55\% of Egypt's employees are «not engaged» and 32\% are «actively disengaged» which means they are unhappy and unproductive. This is an indication for a big problem (Gallop Study, 2015) (Hanan, et al., 2014).

Managers should promote engagement for numerous reasons, such as the employees' mental health; it was found that engaged employees have healthier mental state and tend to be more productive than employees who are not engaged, which affects the organization's competitive advantage (May, et al., 2004) (Crabtree, 2005) (Macey et al., 2009). Moreover, a clear strong relationship between productivity and organizational performance was found; the higher the employee engagement, the better the financial performance, the less the turnover rate, and the higher the productivity (Baumruk, 2006). It was found that when organizations have high engagement their operational income increase by 19\% (Perrin, 2007).

\section{Drivers of Employee Engagement}

There are drivers that can efficiently and effectively lead to employee engagement. Those drivers are represented in; the job's nature, an individual's relationships with coworkers as well as personal relationship with one's manage, employee development opportunities, the organization's culture, the communication's quality, the management's styles, and the levels of trust and respect within the organization (The Conference Board, 2006) (Lockwood, 2007).

The levels of engagement and its drivers are not constant; however, they differ from one organization to the other; due to numerous factors, such as: the different organizations' structures, cultures and policies, the different employee groups, and the different individuals and t jobs (Robinson, 2007) (Bakker \& Demerouti, 2007).

The most important drivers for engagement can be considered the involvement, career progression, training and development, communication, one's belief in company's path, and participation in company decisions (Melcrum, 2007) (Robinson et al., 2007). 
Performance management and planning, such as appraisals and trainings; are very important factors to be considered when attempting to increase employee engagement (Melcrum's, 2007).

\section{Managers}

Nowadays managers take time to understand their employees' values; they motivate them, and work on creating a strong connection with them; which in return has a positive effect on the level of employees' commitment.

Managers can increase employee engagement by allowing the participation in decision making, as well as providing feedback on the performance (Buchner, 2007) (Bakker et al., 2007).

The more engaged the employee, the more likely he is to consider his job supportive, due to the available resources that can be used to help employees deal with work stress and pressures(Schaufeli \& Salanova, 2008)(Buckingham and Coffman, 1999) (Crabtree, 2005).

Engagement can be supported by respectful treatment of employees, self-awareness, communication, transparency, and ethical behavior (Sinclair et al., 2008). Organization's management has a great influence on engagement (Macey and Schneider, 2008).

Managers are the most important employee engagement driver and their attitude affect the employees' relationships (Melcrum, 2007) (Cleland et al., 2008: 5). Managers who respect their employees and make them feel confident in the company and its future; are capable of increasing employee engagement (Jack, 2008) (Leiter and Maslach, 1998: 351).

\section{Organizational Cognition}

In order for organizations to be creative, they need to engage workers. However, it has to be noted that engagement is not the same as involvement; involvement is a result of an intellectual judgment which was formed due to satisfying the job needs, however, engagement is the result of feeling of fairness and commitment (May et al., 2004). Employees always need motivation and feeling of commitment (Roffey Park Institute, 2008) (Reichers \& Schneider, 1990).

Organizational fairness deals allows employees to decide if they have been treated justly in their jobs or not; and this in return affects their behavior, attitude, performance, and the organization's success (Moorman, 1991) (Coetzee, 2005).

Informational fairness is providing employees with the needed information regarding procedures, the way they are applied and the expected outcome (Greenberg, 1993).

Macey et al. (2009) model suggests the following:

1- Employee engagement has a clear state

2- This state results in engagement

3- Engagement enhances performance (Hyvönen, 2009).

The work environment, organizational procedures, management, values, role challenges, work-life balance, information provided, and reward; forecast the engagement (Glen, 2006).

\section{Clarity of Responsibilities}

HR systems and management practices should be used when dealing with employees to produce a culture of engagement at workplace (Lockwood, 2007).

To support employee engagement, employee health and safety programs can be used (Grawitch, 2006).

Clear HR policies, assurance employee well-being, work-life balance, performance management, efficient communication, and increase employee engagement (Robinson et al., 2004: 129-147) (Anitha, 2014: 308-323) (Schneider, et al., 2009: 23-27) (Graen, 2008: 74-75).

\section{Compensation}

If a fair system of exchange is implemented, employees would be driven to engage in their jobs (Blau, 1964: 363-366). When employees receive rewards, they become more engaged. Lack of rewards would lead to dissatisfaction ${ }^{(1)}$ (Saks, 2006: 600-619) (Maslach, et al., 2001: 397- 422).

(1) The social exchange theory (SET) is the most accepted and widely used theory in the recent research on employee engagement 
Engagement is affective-cognitive, and Work Life Balance enhances it by providing flexible working hours (Schaufeli et al., 2002) (Blates et al., 1999).

\section{Training and Development}

Training focuses on providing employees with tools and assets represented in knowledge, skills and capabilities that are needed for employees' career growth. It helps in the completion of job easily by reducing employee's physical and mental expenses. (Baker and Demerouti, 2008)

The model below explains the relation between managers, organization cognitive, policies, compensation, training, and employee engagement.

A model suggested by the researcher

\section{Methodology}

Testing the hypotheses proposed in the previous model started in April 2017 and ended in June 2018, involved developing and administering a questionnaire to a convenience sample of employees of the Ministry of Health and Population in Egypt, assessing the reliability of the scales employed. The statistical analysis was-conducted using SPSS version 23.

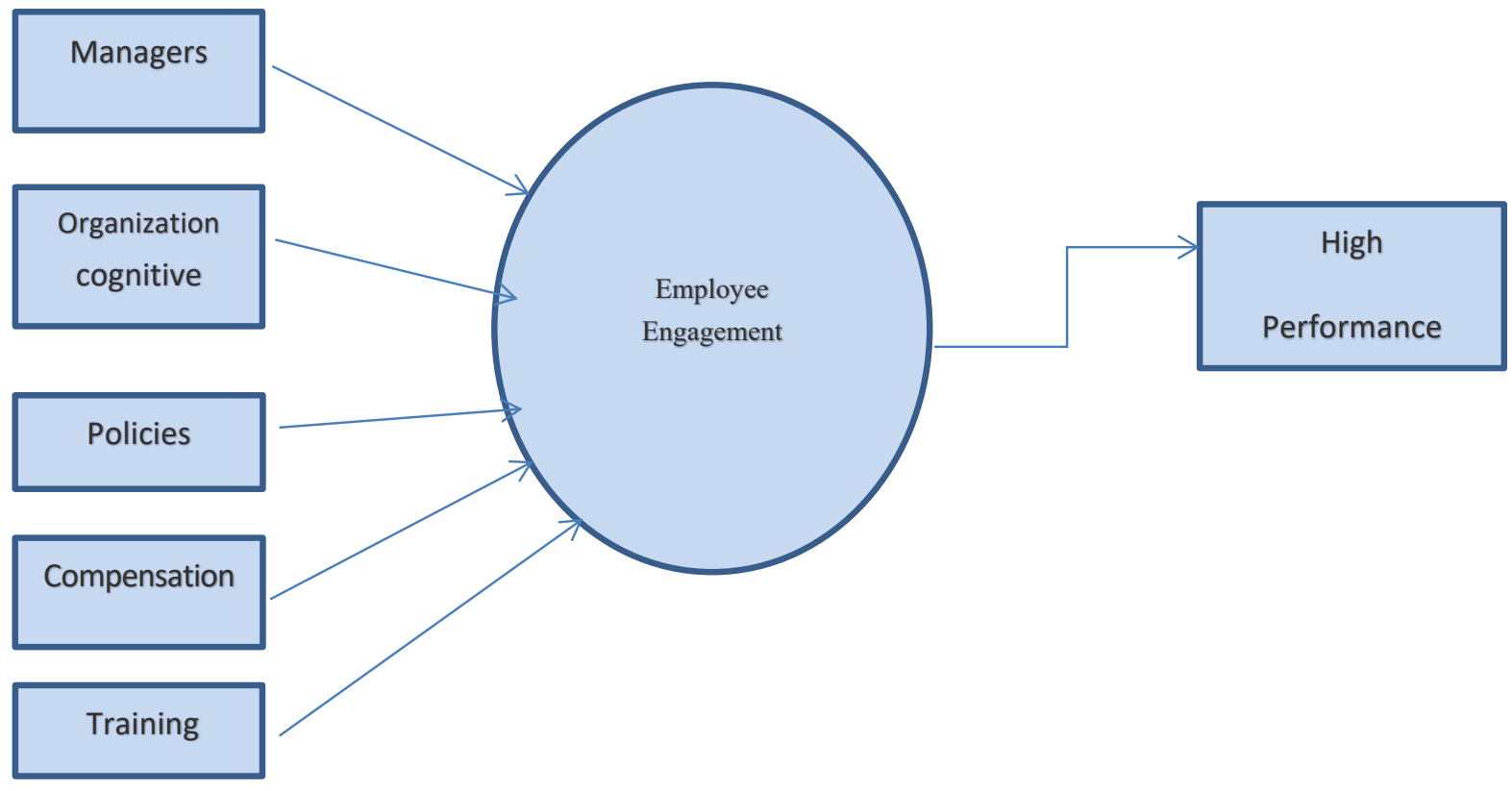

\section{Sample}

The population of the study included the employees in the public sector in Egypt. The number of employees reached 780,200 workers in 2016/2017(1).

The total number of questionnaires distributed was 550. After removing incomplete questionnaires, the number of usable questionnaires was 476 .

$N=\frac{Z^{2} p(1-p)}{d^{2}}$

$\mathrm{N}=$ Sample size is 386 samples

$Z=1.96$ is equal to the value of the natural variable standard.

$\mathrm{d}^{2}=$ the size of the allowed error 0.05

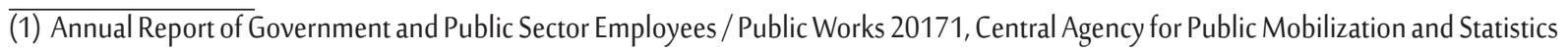




\section{Time Frame}

From April 2017-March 2018.

\section{Limitation of the study}

A random sample was taken from

- Employees of the Ministry of Health

- Employees of the Ministry of Education

- Employees of the Ministry of Electricity

\section{Measures}

The questionnaire included questions to assess the variables affecting both employee engagement and performance. Those variables are represented in: Managers, organizational cognitive, compensation, clarity of responsibility, and training; and there effect on employee engagement and performance. Thus, seven variables were measured using Likert scale, which allows individuals to express how much they agree or disagree with a particular statement. Answers ranged from 1 (strongly disagree) to 5 (strongly agree). The questionnaire consisted of seven parts; each consisted of questions measuring the related variable.

The questionnaire consisted of the following questions:

\section{Managers}

1- Managers pay attention to employees' promotions

2- I am glad to work with my manager.

3- My manager is considerate.

4- If someone asked me to describe the best manager, I'll describe my manager.

5- My manager allows me to participate in decision-making.

6- I do not want to work with another manager.

7- I do not want to leave work.

8- My manager always encourages me.

\section{Organizational Cognitive}

1- My workplace recognizes my efforts.

2- I will not leave my workplace because I feel special.

3- If someone asked for the best workplace, I will say my workplace's name.

4- I feel confident in my workplace.

5- I feel responsible in my workplace.

6- I do not intend to leave my workplace because my efforts are appreciated.

\section{Clarity of Responsibility}

1- Policies and regulations lead me to work professionally.

2- I will not be able to leave my workplace because it has clear policies, duties and responsibilities

\section{Training}

1- I do not want to leave my workplace because I get training and skills improvement.

2- My workplace cares about improving my skills.

3- Training reduces the effort required from me.

\section{Compensation}

1- I think that the promotions are fair.

2- I I am satisfied with the compensations I receive.

3- My effort is equivalent to the compensations I receive.

4- I do not want to leave my job, due to the compensations I receive.

5- The more compensation I receive the more loyal I become to my workplace. 


\section{Employee Engagement}

1- I participate in decision-making.

2- I do not intend to leave my workplace because it enhances my skills.

3- The more recognition I receive the more loyal I become to my workplace.

4- The more I participate in decision making the more loyal I become to my workplace.

5- My workplace cares about my personal problems.

\section{Performance}

1- The more loyal I become to my workplace, the better my performance becomes.

2- The more I participate in decision-making, the better my performance becomes.

3- I perform better when I am not stressed.

4- I perform better when there are flexible working hours.

5- I perform better when there is a monthly fun day.

Once the questionnaire was answered, each variable's mean answers were calculated and then the means were taken and SPSS was used to measure the correlation between each variable and the employee engagement and performance.

According to Table (1), most of the respondents range from agree and disagree for managers $(M=3.47, S D=1.257)$, organization cognitive $(M=3.27, S D=1.065)$, compensation $(M=3.5336, S D=1.256)$, clarity of responsibility $(M=2.4013$, $\mathrm{SD}=0.60933)$, training $(M=2.8046, \mathrm{SD}=0.83203)$, employee engagement $(M=3.7353, S D=1.06291)$ which affects the performance $(M=3.8676, S D=1.08643)$.

Table 1. Descriptive Statistics for Variables

\begin{tabular}{|c|c|c|c|}
\hline & Mean & $\begin{array}{c}\text { Std. } \\
\text { Deviation }\end{array}$ & $\mathrm{N}$ \\
\hline Manager & 3.47 & 1.257 & 476 \\
\hline Organization cognitive & 3.27 & 1.065 & 476 \\
\hline Compensation & 3.5336 & 1.25695 & 476 \\
\hline Clarity of responsibility & 2.4013 & 0.60933 & 476 \\
\hline Training & 2.8046 & 0.83203 & 476 \\
\hline Employee engagement & 3.7353 & 1.06591 & 476 \\
\hline Performance & 3.8676 & 1.08643 & 476 \\
\hline
\end{tabular}

Table2. Reliability Coefficients of Variables Used in This Study

\section{Evaluating Reliability}

Data analysis was conducted. All scales were first subjected to reliability analysis. The Alpha Correlation Coefficient (ACC) was used. Item analysis indicated that dropping any item from the scales would not significantly raise the alphas.

The reliability measures, in terms of Cronbach's alpha, reached a recommended level of 0.70 as an indicator for adequate internal consistency.

\begin{tabular}{lccc}
\hline \multicolumn{1}{c}{ Variable } & $\begin{array}{c}\text { No. of } \\
\text { items }\end{array}$ & $\begin{array}{c}\text { Cronbach's } \\
\text { Alpha }\end{array}$ & Reliability \\
\hline 1 Managers & 8 & 0.814 & 0.902 \\
\hline 2 Organizational Cognitive & 6 & 0.605 & 0.778 \\
\hline 3 Clarity of Responsibility & 2 & 0.711 & 0.843 \\
\hline 4 Compensation & 3 & 0.730 & 0.854 \\
\hline 4 Training & 5 & 0.684 & 0.827 \\
\hline 6 Employee engagement & 5 & 0.725 & 0.851 \\
\hline 7 Performance & 5 & 0.798 & 0.893 \\
\hline
\end{tabular}

\section{Data Analysis and Results}

Pearson correlation coefficients were calculated to investigate the relationships between factors as shown in Table 3.

The table (3) shows that managers have the highest effect on employee engagement and performance, followed by organizational cognition, compensation, clarity of responsibility and training.

It was also noted that the employee engagement has a direct effect and relationship on performance. The more the employee engagement, the higher the performance. The graph below illustrates this relationship.

Table3. Correlation Matrix for Variables

\begin{tabular}{|c|c|c|c|c|c|c|c|c|}
\hline & & Manager & $\begin{array}{c}\text { Organizational } \\
\text { Cognitive }\end{array}$ & $\begin{array}{c}\text { Compensa- } \\
\text { tion }\end{array}$ & $\begin{array}{c}\text { Clarity of Re- } \\
\text { sponsibility }\end{array}$ & Training & $\begin{array}{c}\text { Employee } \\
\text { engagement }\end{array}$ & $\begin{array}{l}\text { Perfor- } \\
\text { mance }\end{array}$ \\
\hline \multirow[t]{3}{*}{ Manager } & Pearson Correlation & 1 & $0.805^{* *}$ & $0.724^{* *}$ & $0.709^{* *}$ & $0.661^{* *}$ & $0.892^{* *}$ & $0.922^{* *}$ \\
\hline & Sig.(2-tailed) & & 0.000 & 0.000 & 0.000 & 0.000 & 0.000 & 0.000 \\
\hline & $\mathrm{N}$ & 476 & 476 & 476 & 476 & 476 & 476 & 476 \\
\hline
\end{tabular}




\begin{tabular}{|c|c|c|c|c|c|c|c|c|}
\hline & & Manager & $\begin{array}{l}\text { Organizational } \\
\text { Cognitive }\end{array}$ & $\begin{array}{c}\text { Compensa- } \\
\text { tion }\end{array}$ & $\begin{array}{c}\text { Clarity of Re- } \\
\text { sponsibility }\end{array}$ & Training & $\begin{array}{c}\text { Employee } \\
\text { engagement }\end{array}$ & $\begin{array}{l}\text { Perfor- } \\
\text { mance }\end{array}$ \\
\hline \multirow{3}{*}{$\begin{array}{l}\text { Organizational } \\
\text { Cognitive }\end{array}$} & Pearson Correlation & $0.805^{* *}$ & 1 & $0.741^{* *}$ & $0.555^{* *}$ & $0.513^{* *}$ & $0.890^{* *}$ & $0.838^{* *}$ \\
\hline & Sig.(2-tailed) & 0.000 & & 0.000 & 0.000 & 0.000 & 0.000 & 0.000 \\
\hline & $\mathrm{N}$ & 476 & 476 & 476 & 476 & 476 & 476 & 476 \\
\hline \multirow[t]{3}{*}{ Compensation } & Pearson Correlation & $0.724^{* *}$ & $0.741^{* *}$ & 1 & $0.586 * *$ & $0.545^{* *}$ & $0.754^{* *}$ & $0.682 * *$ \\
\hline & Sig.(2-tailed) & 0.000 & 0.000 & & 0.000 & 0.000 & 0.000 & 0.000 \\
\hline & $\mathrm{N}$ & 476 & 476 & 476 & 476 & 476 & 476 & 476 \\
\hline \multirow{3}{*}{$\begin{array}{l}\text { Clarity of Re- } \\
\text { sponsibility }\end{array}$} & Pearson Correlation & $0.709^{* *}$ & $0.555^{* *}$ & $0.586 * *$ & 1 & $0.678^{* *}$ & $0.678^{* *}$ & $0.681^{* *}$ \\
\hline & Sig.(2-tailed) & 0.000 & 0.000 & 0.000 & & 0.000 & 0.000 & 0.000 \\
\hline & $\mathrm{N}$ & 476 & 476 & 476 & 476 & 476 & 476 & 476 \\
\hline \multirow[t]{3}{*}{ Training } & Pearson Correlation & $0.661^{* *}$ & $0.513^{* *}$ & $0.545^{* *}$ & $0.678^{* *}$ & 1 & $0.617^{* *}$ & $0.558^{* *}$ \\
\hline & Sig.(2-tailed) & 0.000 & 0.000 & 0.000 & 0.000 & & 0.000 & 0.000 \\
\hline & $\mathrm{N}$ & 476 & 476 & 476 & 476 & 476 & 476 & 476 \\
\hline \multirow{3}{*}{$\begin{array}{c}\text { Employee } \\
\text { engagement }\end{array}$} & Pearson Correlation & $0.892^{* *}$ & $0.890 * *$ & $0.754 * *$ & $0.678^{* *}$ & $0.617^{* *}$ & 1 & $0.950 * *$ \\
\hline & Sig.(2-tailed) & 0.000 & 0.000 & 0.000 & 0.000 & 0.000 & & 0.000 \\
\hline & $\mathrm{N}$ & 476 & 476 & 476 & 476 & 476 & 476 & 476 \\
\hline \multirow[t]{3}{*}{ Performance } & Pearson Correlation & $0.922^{* *}$ & $0.838 * *$ & $0.682 * *$ & $0.681^{* *}$ & $0.558 * *$ & $0.950 * *$ & 1 \\
\hline & Sig.(2-tailed) & 0.000 & 0.000 & 0.000 & 0.000 & 0.000 & 0.000 & \\
\hline & $\mathrm{N}$ & 476 & 476 & 476 & 476 & 476 & 476 & 476 \\
\hline
\end{tabular}

**. Correlation is significant at the 0.01 level (2-tailed)

\section{Conclusion}

Based on the study, it can be concluded that the most important factors affecting the employee engagement are managers, organization cognitive, compensation, clarity of responsibilities, and finally training.

Countries facing economic challenges and aiming to improve their economy must first improve their human resources capital and pay close attention to their employees.

Employee engagement helps in de-

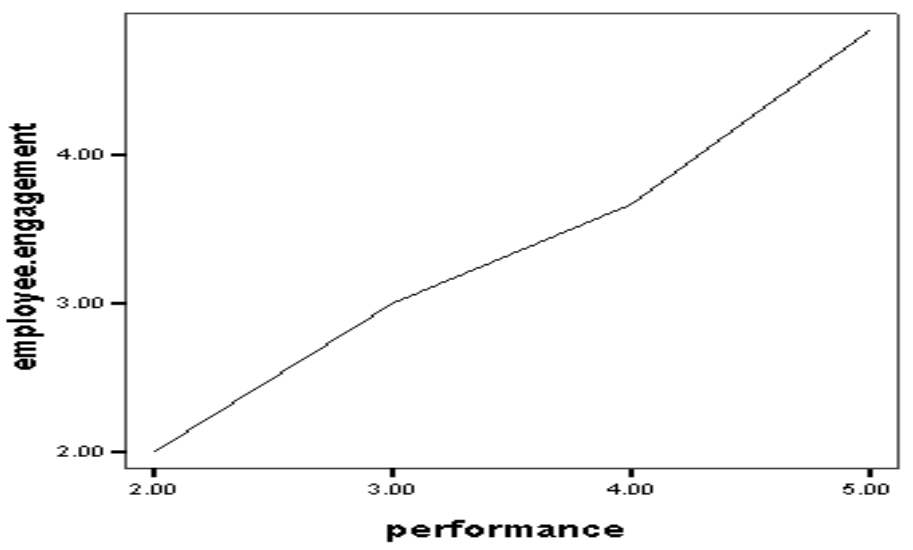
creasing the rates of absenteeism, improves productivity, and enhances the service's quality. Without employee engagement; productivity and service quality shall decrease (Nahrgang, Morgeson \& Hofman, 2011; Harter, et al. 2009; Gonring, 2008).

Employee engagement should be a part of the work environment in order to increase productivity, satisfaction, and loyalty, as well as, enhance performance.

\section{Recommendations}

In order to increase employees' engagement, the management has to pay very close attention to its employees. This attention can be represented in communicating and discussing the problems they face in the workplace and outside of it, allowing them to participate in decision-making; which will in return improve their performance. Employees' efforts have to be recognized and their evaluation should be based on their actual performance. Employees' responsibilities and duties have to be very clear to enhance their performance and eliminate the risk of misunderstanding their duties.The organization's culture should allow teamwork, and support learning and communication. 


\section{References}

-Saks, M. A. (2006). «Antecedents and consequences of employee engagement», Journal of Managerial Psychology, Vol. 21, No.7. pp. 600-619. 21 No. 7(DOI 10.1108/02683940610690169), pp. 600-619.

- $\quad$ Adams, J. (1965). «Inquiry in social exchange», In: Berekowitz, L. (Ed.) Advances in Experimental Social Psychology. Academic Press, New York, NY, pp. Vol. 2 pp. 267-299.

Anitha, J. (2014). «Determinants of employee engagement and their impact on employee performanc», International Journal of Productivity and Performance Management, Vol. 63, Iss. 3, pp. 308-323.

- $\quad$ Baker, A. B. and Demerouti, E. (2008). «Towards a model of work engagement», Career Development International, Vol. 13 (3), pp. 209-223.

- $\quad$ Bakker, A. B.; Hakanen, J. J.; Demerouti, E. and Xanthopoulou, D. (2007). «job resources boost work engagement, particularly when job demands are high», Journal of Applied Psychology, 99, 274-284.

- Bakker, A. B. and Demerouti, E. (2007). «The job demands-resources model: State of the art», Journal of Managerial Psychology, 22, 309-328.

Baltes, B. B.; Briggs, T. E.; Huff, J. W.; Wright, J. A. and Neuman G. A. (1999). «Flexible and compressed workweek schedules: A meta-analysis of their effects on work-related criteria», Journal of Applied Psychology, Vol. 84, No. 4, pp. 496-513.

- Baumruk, R. (2006), «Why managers are crucial to increasing engagement», Strategic HR Review, January/ February.

Blau, P. (1964). «Exchange and power in social life», Annual Review of Psychology, Vol. 78 (118), 32, pp. 363-366.

- Blessing White. (2006). Employee engagement report 2006. Blessing White, Inc. Princeton, New Jersey. [Online] https://www.gpstrategies.com.

- $\quad$ Blessing White. (2008). The state of employee engagemen. Blessing White, Inc. Princeton, New Jersey. [Online] https://www.gpstrategies.com.

- $\quad$ Buchner, T.W. (2007). «Performance management theory: A look from the performer's perspective with implications for HRD», Human Resource Development International, 10, 59-73.

Buckhingham, M. and Coffman, C. (1999). First, break all the rules: What the world's greatest managers do differently. New York: NY: Simon \& Shuster.

- $\quad$ Cleland, A., Mitchinson, W. and Townend, A. (2008). Engagement, assertiveness and business performance: $A$ new perspective. Ixia consultancy ltd.

Coetzee, M. (2005). «The fairness of affirmative action: an organizational justice perspective», Master's Thesis. University of Pretoria, Pretoria

- $\quad$ Cohen, A. (1991). «Career stage as a moderator of the relationship between organizational commitment and its outcomes: A meta-anlaysis», Journal of Occupational Psychology, Vol. 64, pp. 253-268.

Conference Board. (2006). Employee engagement: $A$ review of current research and its implications, The conference board.

Crabtree, S. (2005). Engagement keeps the doctor away: A happy employee Is a healthy employee, according to a GMJ survey. Washington, DC: The Gallup Organization. available at: http:// gmj.gallup.com/ content/14500/Engagement-Keeps-Doctor-Away.aspx. Accessed December 12, 2005.

Crim, Dan and Gerard H. Seijts. (2006). «What engages employees the most or, the ten C's of employee engagement «. P. Ivey Business Journal, affective-motivational state of fulfilment'Maslach C, Schaufeli WB, Leiter MP (2001), 'Job burnout', Annual review of

- $\quad$ Fay, D. and Sonnentag, S. (2002). «Rethinking the effects of stressors: a longitudinal study on personal initiative», Journal of Occupational Health Psychology, 7, 221-234

Frese, M. (2008). «The word is out: we need an active performance concept for modern workplaces», Industrial and Organizational Psychology, 1, 67-69. 
Gallop Study. (2015). State of global workplace. [Online] Available at: http://www.gallup.com/ services/178517/state-global-workplace.aspx [Accessed 30 June 2015].

Glen, C. (2006). «Key skills retention and motivation: the war for talent still rages and retention is the high ground», Industrial and Commercial Training, 38 (1), 37-45.

Graen, G. B. (2008). «Enriched engagement through assistance to systems' change: a proposal», Industrial and Organizational Psychology, 1, 74-75.

Grawitch, M. J.; Gottschalk, M. and Munz, D. C. (2006). «The path to a healthy workplace: A critical review linking healthy workplace practices, employee well-being, and organizational improvements», Consulting Psychology Journal: Practice and Research, Vol. 58 (3), pp. 129-147.

Greenberg, J. (1993). «The social side of fairness: interpersonal and informational classes of organizational justice», In: Corponzona, R. (Ed.) Justice in the workplace: Approaching fairness in human resource management.

Hanan M.; Antoine L. and Sanchez, C. (2014). Growing without changing: A tale of Egypt's weak productivity growth. Working paper No. 172, European Bank for reconstruction and development Harter, J. K.; Schmidt, F. L. and Hayes, T. L. (2002). «Business-unit-level relationship between employee satisfaction, employee engagement, and business outcomes: A meta-analysis», Journal of Applied Psychology, 87, 268-279.

Hornung, S.; Rousseau, D. M.; Glaser, J.; Angerer, P. and Weigl, M. (2010). «Beyond top-down and bottom-up work redesign: Customizing job content through idiosyncratic deals», Journal of Organizational Behavior, 31, 187-215.

HR Director. (2008). «Engagement by design», Hemsley Fraser, Issue, 49

Hyvönen, K.; Feldt, T.; Salmela-Aro, K.; Kinnunen, U. and Mäkikangas, A. (2009). «Young managers drive to thrive: A personal work goal approach to burnout and work-engagement», Journal of Vocational Behavior, 75, 183-196.

Ipsos, Mori. (2008). Employee relationship management employee engagement, www.ipsos-mori.com/researchspecialisms/loyalty/youremployees/engagement. Ashx

- Jack, Wiley. (2008). Executive director. Kenexa Research Institute quoted in Wayne, 2008.

- Johnson, M. (2004). The new rules of engagement: life work balance and employee commitment. The Chartered Institute of Personnel and Development.

- Kahn, W. A. (1992). «To be full there: Psychological presence at work», Human Relations, 45, 321-349.

- Lawler, E. E., III. (2008). «Make human capital a source of competitive advantage», Organizational Dynamics, 38.

Leiter, M. P. \& Maslach, C. (1998). «Burnout», In H. S. Friedman (Ed.), Encyclopedia of Mental Health, Vol. 1, New York: Academic Press. p. 351.

Lockwood, N. (2007). Leveraging employee engagement for competitive advantage: HR's strategic role. HR Magazine, Vol. 52, (3) special section, pp. 1-11.

- $\quad$ Lockwood, N. R. (2007). «Leveraging employee engagement for competitive advantage: HR's strategic role», Society for Human Resource Management Quarterly, 1/4

- Macey, W. H., \& Schneider, B. (2008). The meaning of employee engagement. Industrial and Organizational Psychology, 1, 3-30.

Macey, W. H.; Schneider, B.; Barbera, K. M. and Young, S. A. (2009). Employee engagement: Tools for analysis, practice and competitive advantage. Malden, WA: Wiley- Blackwell.

Macey, W. H; Schneider, B. (2008a). «The meaning of employee engagement», Industrial and Organisational Psychology, 1, 3-30

Maslach, C.; Schaufelli, W. B. and Leiter, M. P. (2001). «Job burnout», Annual Review of Psychology, Vol. 52, No. 1, pp. 397-422.

May, D. R., Gilson; R. L. and Harter, L. M. (2004). «The psychological conditions of meaningfulness, afety and availability and the engagement of the human spirit at work», Journal of Occupational and Organizational Psychology, Vol. 77, pp. 11-37. 
May, D. R.; Gilson, R. L. and Harter, L. M. (2004). «The psychological conditions of meaningfulness, safety, availability, and the engagement of the human spirit at work», Journal of Occupational and Organizational Psychology, 77, 11-37.

- Melcrum. (2007). The practitioner's guide to essential techniques for employee engagement. Melcrum Publishing Limited.

- Me Mercer. (2007). Exploring the gobal drivers of employee engagement, www.mercer.com/ referencecontent.htm2idContent $=1281670$

- Moorman, R. (1991). «Relationship between organizational justice and organizational citizenship behaviors: do fairness perceptions influence employee citizenship?», Journal of Applied Psychology, Vol. 76, No. 6, pp. 845-855.

- Reichers, A. E. and Schneider, B. (1990). «Climate and culture: An evolution of constructs», In: B. Schneider (Ed.), Organizational climate and culture, (pp. 5-39). San Fransico, CA: Jossey- Bass.

- $\quad$ Robinson, D. (2007). Engagement is marriage of various factors at work. Thought Leaders.

- $\quad$ Robinson, D.; Perryman, S. and Hayday, S. (2004). Institute for Employment Studies. Brighton. Lawrence Erlbaum Associates, Englewood Cliffs, NJ., pp. 79-103.

- $\quad$ Robinson D.; Perryman S. and Hayday S. (2004). «he Drivers of employee engagement. UK: Institute for Employment Studies, IES Report 408.

- $\quad$ Roffey Park Institute. (2008). www.roffeypark.com/SiteCollectionDocuments/engagement\%20 diagnostic\%20flyer.pdf

- Rothbard. (2001). Schaufeli, W. B.; Salanova, M.; Gonzalez-Roma, V. and Bakker, A. B. (2002). «The measurement of engagement and burnout: A two sample confirmatory factor analytic approach», Journal of Happiness Studies, 3, 71-92.

- Schaufeli, W. B. \& Salanova, M. (2008). «Enhancing work engagement through the management of human resources», In: K. Näswall, J. Hellgren \& M. Sverke (Eds.), The individual in the changing working life, (pp. 380-402). New York: Cambridge University Press.

- $\quad$ Schaufeli, W. B. (2013). «What is engagement?» In: C. Truss, K. Alfes, R. Delbridge, A. Schantz \& E. Soan (Eds), Employment Engagement in Theory and Practice. London: Routledge.

- Schaufeli, W. B.; Salanova, M.; Gonzalez-Roma, V. and Bakker, A. B. (2002). «The measurement of engagement and burnout: A two sample confirmatory factor analytic approach», Journal of Happiness Studies, Vol. 3, pp. 71-92.

- Schneider, B. Marcey; W. H. and Barbera, K. M. (2009). «Driving customer satisfaction and financial success through employee engagement», People and Strategy, Vol. 32, No. 2, pp. 23-27.

- Sinclair, A.; Robertson-Smith G. and Hennessy, J. (2008). The management agenda. Roffey Park Institute

- Towers, Perrin. (2007). Largest Ever Studyof Global Workforce Finds Senior Management Holds Trigger to Unleash Talent Potential, www.towersperrin.com/tp/showdctmdoc.jsp2url=HR_Services/Canada/Englis/Press_Releases/2007/20071022/2007_10_22.htm\&country=global

- Wahba, D. (2013). «The impact of foreign currency crisis on bank procedures and operations in Egypt during 2011-2013», Magazine of Egyptian Banking Institute, pp. 5-15.

- Wayne, P. A. (2008). The kenexa research institute reveals exactly how engaged employees are andwhatexactly:EmployeeEngagement.Meanshttp://biz.yahoo.com/iw/080911/0432733. 